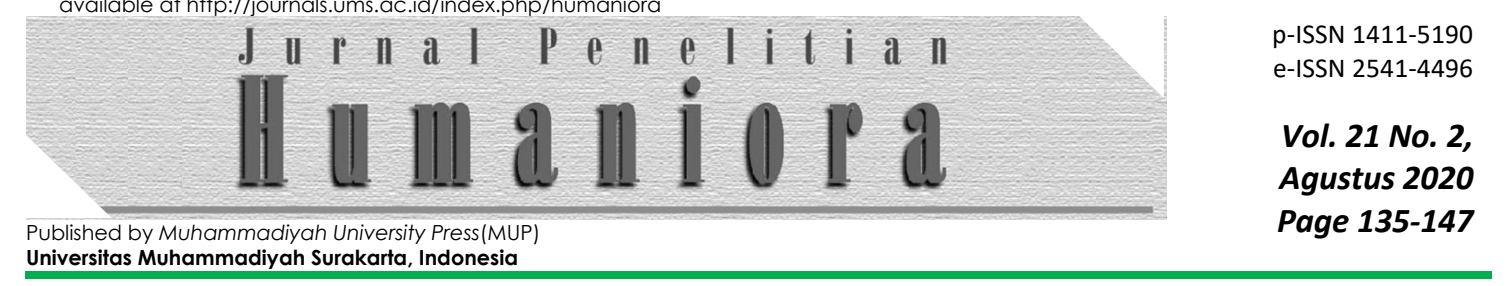

\title{
MUATAN MORAL DALAM CERITA NAGASASRA DAN SABUK INTEN KARYA S.H. MINTARDJA
}

\author{
Tri Handito' ${ }^{1}$ Kasiati $^{2}$, Septi $^{3}$ \\ ${ }^{1-3}$ Magister Administrasi Pendidikan, Universitas Muhammadiyah Prof. Dr. Hamka, Indonesia
}

DOI: 10.23917/humaniora.v20i2.9744

Submit: 2 Januari 2020. Revisi: 29 Juli 2020 . Diterima: 17 Agustus 2020

Available Online: 21 Agustus 2020. Periode Terbit: Agustus 2020

\begin{tabular}{l}
\hline Kata Kunci \\
\hline moral, \\
value, \\
nagasasra \\
\\
\\
\hline Corresponding Author \\
\hline Tri Handito \\
Universitas Muhammadiyah \\
Prof. Dr. Hamka, Indonesia \\
Email: \\
tugaspkn_trihandito@yahoo \\
.co.id \\
Phone: +6287880843340
\end{tabular}

Abstrak

This study aims to identify the content of moral values contained in the Nagasasra and Sabukinten stories written by SH Mintardja volumes I through volume III. This research is a content analysis research with a qualitative approach. In this research the researcher becomes the main instrument of data collection. In the process of collecting data, researchers used research aids in the form of data cards and check lists. Data cards were used to record sentences in the form of conversations and portrayals of the situation and behavior of characters in the Nagasasra and Sabuk Inten stories. The captured data was then presented in the form of a statement in the form of a description of moral values. The results of the study found that there were good moral values and bad moral values that are manifested in various depictions of the behavior of the characters. Good behavior includes godly values (in the form of belief in the existence and power of God, surrender/ surrender to God, giving thanks, repenting, praying, and praying), loyalty (in the form of loyalty between husband and wife, loyalty of a soldier towards the king / leadership, and loyalty to the land of his birth), love for the country, love for the environment, responsibility, honesty, being respectful and polite, humble, and the delivery of moral values in the form of song. The bad morals were reflected in bad behavior, including not believing in the existence and power of God, cruel, greedy, immorality, cunning / cheating, arrogant / proud, defaming, stealing / robbing, low self-esteem, despair, and destructive natural. The most moral values found in the Nagasasra and Sabuk Inten volumes I through III are the value of helping $(31.15 \%)$, the value of courtesy (26.23\%), the value of God (16.39\%), the value of loyalty (9.84\%), the value of responsibility $(6.56 \%)$, the value of humility $(4.92 \%)$, the value of love for nature $(3.28 \%)$, and moral messages in the form of song $(1.64 \%)$. 


\section{PENDAHULUAN}

Masyarakat merupakan kumpulan individu yang begitu kompleks dengan perbedaan karakter dan perbedaan kepentingan. Adanya perbedaan kepentingan berpotensi menimbulkan konflik manakala terjadi benturan kepentingan antarindividu atau antarkelompok atau antara individu dengan kelompok. Konflik tersebut menyebabkan keseimbangan dalam masyarakat menjadi terganggu. Untuk memulihkan agar keseimbangan masyarakat kembali seperti semula serta untuk melindungi pemenuhan kepentingan masing-masing individu atau kelompok dalam masyarakat, diperlukan suatu norma atau kaidah. Salah satu norma adalah norma moral. Moral merupakan ajaran tentang kesusilaan. Seseorang dikatakan baik secara moral apabila bertingkah laku sesuai dengan norma kesusilaan yang berlaku dalam masyarakat di mana ia berada. Sebaliknya, jika seseorang bertingkah laku menyimpang dari norma kesusilaan, maka ia dikatakan buruk secara moral. Jadi, norma moral merupakan tolok ukur yang dipakai oleh masyarakat untuk mengukur kebaikan seseorang atau sekelompok orang.

Dari paparan di atas terlihat bahwa antara manusia dengan moral memiliki hubungan yang sangat erat. Secara umum moral mengarah pada pengertian ajaran tentang apa yan dinilai baik dan apa yang dinilai buruk yang diterima umum mengenai perbuatan, sikap, dan sebagainya. Moral selalu berkaitan dengan kehidupan manusia. Nilai moral dikaitkan dengan tindakan yang langsung berkenaan dengan nilai pribadi manusia/masyarakat (Soenarjati dan Cholisin, 1989). Jadi, moral selalu dikaitkan dengan baik buruknya manusia sebagai manusia. Artinya, nilai moral hanya ada dalam perilaku manusia. Namun, tidak semua perilaku manusia dapat diberi penilaian moral. Penilaian moral hanya dapat dikaitkan dengan perbuatan manusia yang disengaja yang dilakukan secara sadar dan dikehendaki.

Moral mempunyai hubungan yang erat dengan karya sastra. Kata sastra berasal dari bahasa Sansekerta, yaitu kata cas yang berarti 'wejangan atau ajaran' dan tra yang berarti alat. Jadi, sastra dapat diartikan sebagai alat untuk mengajar atau memberi wejangan. Adapula yang menyebut sastra dengan istilah susastra. Susastra berasal dari kata su yang berarti 'baik atau indah' dan sastra yang berarti 'tulisan'. Jadi, susastra berarti semua tulisan yang mengandung nilai kebaikan yang ditulis dengan bahasa yang indah (Abdulrani, 1996). Keindahan bentuk hasil karya sastra terlihat dari penampilan fisik maupun isi karya sastra tersebut.

Hubungan yang erat antara nilai moral dengan karya sastra terlihat dari fungsi karya sastra. Salah satu fungsi karya sastra adalah fungsi moralitas (Abdulrani, 1996). Sastra mempunyai fungsi moralitas karena kandungan nilai baik dan buruk yang terdapat di dalamnya. Sastra tak lain adalah dunia yang menawarkan moral dan moral itu sendiri sesungguhnya sangat dibutuhkan oleh masyarakat (Sayuti, 2000). Moral di dalam masyarakat dibutuhkan untuk menjaga agar tatanan dan tuntunan yang ada tetap lestari. Di dalam karya sastra moral merupakan sesuatu yang ingin disampaikan oleh pengarang kepada pembacanya, atau merupakan makna yang terkandung/disarankan/diamanatkan. Pesan moral mencakup seluruh persoalan hidup dan kehidupan manusia. Secara garis besar persoalan hidup dan kehidupan manusia dibedakan dalam persoalan hubungan manusia dengan Tuhannya, persoalan hubungan manusia dengan dirinya sendiri, persoalan hubungan manusia dengan lingkungan sosial/sesamanya, dan persoalan hubungan manusia dengan alam sekitar (Nurgiyantoro, 2000).

Sastra merupakan media yan efektif dalam rangka penanaman moral kepada masyarakat, khususnya para pembacanya. Penanaman moral tentu akan lebih mudah apabila disajikan dengan baik dan dengan metode yang menarik. Di sinilah karya sastra dipandang sesuai karena sastra mengutamakan sifat dulce et utile (Nurgiyantoro, 2000). Sifat dulce et utile sebuah karya satra berarti dua hal. Pertama, bila dilihat dari segi bentuk, maka karya sastra adalah sesuatu yang dapat menyenangkan hati para pembacanya. Kedua, dari segi isi suatu karya sastra memiliki kegunaan bagi para pembacanya. Untuk benar-benar mendapatkan manfaat dari sebuah karya sastra, maka suatu karya sastra 
bukanlah sekedar untuk dibaca dan dihayati sebagai pengisi waktu saja, namun perlu diperhatikan bahwa di dalam karya sastra terkandung nilai moral yang bermakna bagi kehidupan.

Di dalam masyarakat, khususnya masyarakat Jawa Tengah dan Daerah Istimewa Yogyakarta (DIY), beredar banyak karya sastra. Salah satu karya sastra yang beredar adalah cerita Nagasasra dan Sabuk Inten. Cerita ini mulai ditulis pada 1964 oleh Singgih Hadi Mintardja (S.H. Mintardja), seorang budayawan kelahiran Yogyakarta, 26 Januari 1933. Pada awalnya cerita Nagasasra dan Sabuk Inten dimuat dalam bentuk cerita bersambung di Surat Kabar Harian Kedaulatan Rakyat. Pada 1966 cerita ini mulai diterbitkan dalam bentuk buku oleh Badan Penerbit Kedaulatan Rakyat.

Cerita Nagasasra dan Sabuk Inten mengambil latar belakang kehidupan masyarakat dan budaya Jawa pada masa kerajaan Demak berada di bawah kekuasaan Sultan Trenggana. Cerita ini dimulai dengan peristiwa hilangnya dua keris pusaka kerajaan Demak, yaitu Keris Kyai Nagasasra dan Sabuk Inten, dari gedung pusaka kerajaan Demak. Dari sini muncul tokoh Mahesa Jenar, seorang perwira kerajaan Demak dari kesatuan Naramanggala (prajurit pengawal raja). Mahesa Jenar meninggalkan segala atribut kebesarannya sebagai seorang perwira kerajaan dengan tujuan untuk mencari, menemukan, dan membawa kembali keris Nagasasra dan Sabuk Inten ke kerajaan Demak (Mintardja, 1983).

Secara umum masyarakat Jawa Tengah dan DIY mengenal cerita Nagasasra dan Sabuk Inten. Hal tersebut disebabkan oleh beberapa hal. Pertama, cerita ini mengambil latar belakang kehidupan dan budaya Jawa sehingga mudah diterima dan dipahami oleh masyarakat Jawa khususnya. Kedua, cerita ini dimuat dalam bentuk cerita bersambung di Surat Kabar Harian Kedaulatan Rakyat. Ketiga, cerita ini diterbitkan dalam bentuk buku, yang berjumlah tiga edisi, oleh Badan Penerbit Kedaulatan Rakyat. Keempat, cerita ini pernah dikemas dalam acara siaran Kethoprak Mataram di RRI Yogyakarta dan ditayangkan dalam acara siaran kethoprak di TVRI Stasiun Yogyakarta. Berbagai kelompok kethoprak tradisional di desa-desa di Jawa Tengan dan DIY juga sering mementaskan lakon Nagasasra dan Sabuk Inten, baik dalam bentuk cerita utuh maupun potongan cerita (pethilan).

Penelitian mengenai muatan moral yang terkandung di dalam cerita Nagasasra dan Sabuk Inten dipandang penting karena beberapa alasan. Pertama, penelitian ini memperkaya khasanah penelitian mengenai cerita Nagasasra dan Sabuk Inten. Beberapa penelitian mengenai cerita Nagasasra dan Sabuk Inten, antara lain Pengkajian Sejarah dan Legitimasi Kekuasaan dalam Novel Api di Bukit Menoreh dan Nagasasra Sabuk Inten Karya S.H Mintardja oleh Drajat Sugiri (Rengganis, 2017), Konstruksi Pengetahuan Jawa dalam Novel Nagasasra dan Sabuk Inten Karya SH Mintardja oleh Joko Widodo dalam Disertasi Program Studi Pendidikan Bahasa Indonesia, Pascasarjana Universitas Negeri Malang tahun 2016 (Widodo, 2016), dan Makna Kejantanan dan Kesetiaan dalam Nagasasra dan Sabuk Inten Karya S.H. Mintardja oleh Prijanto(2014). Kedua, meskipun cerita Nagasasra dan Sabuk Inten telah dikenal luas, namun belum tentu masyarakat mengetahui muatan moral yang terkandung secara komprehensif. Ketiga, nilai moral yang ditemukan dalam cerita Nagasasra dan Sabuk Inten diharapkan dapat menjadi teladan bagi masyarakat. Keempat, bagi Pendidikan Pancasila dan Kewarganegaraan (PPKn), upaya penggalian nilai moral dalam cerita Nagasasra dan Sabuk Inten sangat penting karena nilai moral yang ditemukan dan dideskripsikan dapat memperkaya khasanah pengetahuan tentang moral, di mana moral merupakan salah satu basis keilmuan PPKn.

\section{METODE}

Penelitian tentang muatan moral dalam cerita Nagasasra dan Sabukinten karya S.H. Mintardja merupakan penelitian analisis isi (content analysis) dengan pendekatan kualitatif. Klaus Krippendorff (Shelley, 1984) menyatakan bahwa content analysis is a research technique for making replicable and valid inferences from texts (or other 
meaningful matter) to the contexts of their use (kajian isi adalah suatu teknik penelitian yang dimanfaatkan untuk menarik kesimpulan atau inferensi yang replikatif dan valid dari data berdasarkan konteksnya). Konteks di dalam penelitian analisis isi sangat penting karena sifat dari analisis isi adalah kontekstual. Dengan demikian, karena bersifat kontekstual, maka seandainya berbeda konteksnya, akan dihasilkan simpulan (inferensi) yang berbeda. Weber menyatakan bahwa kajian isi adalah metodologi penelitian yang memanfaatkan seperangkat prosedur untuk menarik simpulan yang sahih dari sebuah buku atau dokumen (Moleong, 2014). Suharsimi-Arikunto menyatakan bahwa analisis isi buku (content analysis) merupakan penelitian yang menghasilkan suatu kesimpulan tentang gaya bahasa buku, kecenderungan isi buku, tata tulis, lay-out, ilustrasi, dan sebagainya (Arikunto, 2013). Analisis isi disebut juga dengan analisis dokumen (Sigit, 1999). Analisis dokumen merupakan usaha untuk mempelajari apa yang tertulis dan dapat dilihat dari dokumen-dokumen. Dokumen tersebut dapat berwujud buku cerita, buku pelajaran (text book), karangan, surat kabar, novel, iklan, gambar, dan sebagainya. Dari berbagai pengertian mengenai analisis isi (content analysis) tersebut dapat disimpulkan bahwa teknil analisis isi dimanfaatkan untuk memahami dan menyimpulkan pesan-pesan simbolik yang terdapat dalam dokumen, karya sastra, artikel. dam sebagainya yang berupa data tidak berstruktur.

Di dalam penelitian ini teknik analisis isi dimanfaatkan untuk memahami pesan simbolik yang berupa nilai-nilai moral yang terkandung dalam cerita Nagasasra dan Sabuk Inten karya S.H. Mintardja seri I sampai III. Pesan simbolik yang berupa nilai moral dalam cerita Nagasasra dan Sabuk Inten merupakan fenomena yang tidak dapat diamati secara langsung sehingga harus diteliti dan diamati.

Objek penelitian ini adalah isi cerita Nagasasra dan Sabuk Inten karya S.H. Mintardja, edisi kedua terbitan tahun 1983 mulai dari jilid I sampai III yang diterbitkan oleh Badan Penerbit Kedaulatan Rakyat Yogyakarta. Isi cerita yang berupa percakapan dan deskripsi tingkah laku para tokoh kemudian dikaitkan dengan teori tentang moral dalam karya sastra.

Instrumen dalam penelitian ini adalah peneliti sendiri (peneliti sebagai key instrument). Artinya, peneliti dengan penetahuan mengenai moral merupakan alat pengumpul data utama. Dalam proses pengumpulan data, peneliti menggunakan alat bantu penelitian berupa kartu data dan daftar cocok (check list). Kartu data digunakan untuk mencatat kalimat-kalimat yang berupa percakapan dan penggambaran tingkah laku para tokoh cerita Nagasasra dan Sabuk Inten. Adapun daftar cocok digunakan untuk menyelidiki perbuatan para tokoh cerita Nagasasra dan Sabuk Inten, apakah termasuk ke dalam moral baik atau buruk. Tokoh tersebut dikategorikan bermoral baik apabila berperilaku sesuai dengan norma yang ada dan disebut bermoral buruk apabila menyimpang dari norma-norma yang ada. Data yang telah dijaring kemudian disajikan dalam bentuk pernyataan yang berupa deskripsi moral. Daftar cocok yang dijadikan pedoman meliputi unsur moral sebagai berikut.

1. Muatan moral yang berhubungan dengan moral terhadap Tuhan Yang Maha Esa, meliputi unsur moral percaya adanya eksistensi Tuhan, beribadah/bersembahyang, bersyukur, menyerahkan diri/pasarah kepada Tuhan.

2. Muatan moral yang berhubungan dengan moral terhadap orang lain, meliputi unsur moral sebagai berikut.

a. Perilaku yang baik, yaitu sopan santun, jujur, bersikap hormat, setia (kepada suami/istri/keluarga, kepada negara/tanah kelahiran, kepada pimpinan), tolongmenolong, rela berkorban demi kepentingan orang lain, rendah hati/tidak sombong, bertanggung jawab, menepati janji.

b. Perilaku yang tidak baik, yaitu tidak sopan, berkhianat (tidak setia), mengejek, sombong (tinggi hati), kejam, berbohong, ingkar janji, malas, iri/dengki, tamak/rakus, mencuri/merampas milik orang lain, licik/curang, berkata kasar/mengumpat, rendah diri, memfitnah, mengadu domba. 
3. Muatan moral yang berhubungan alam sekitar, yaitu berupa unsur moral sayang terhadap hewan, tumbuh-tumbuhan, dan berbagai kekayaan alam yang ada di muka bumi.

Langkah-langkah penelitian muatan moral dalam cerita Nagasasra dan Sabuk Inten karya S.H. Mintardja adalah sebagai berikut.

Pengadaan data meliputi kegiatan penentuan satuan (unit) dan pencatatan. Penentuan satuan (unit) merupakan kegiatan memisah-misahkan data menjadi bagian-bagian yang selanjutnya dapat dianalisis. Satuan unit yang digunakan adalah unit sintaksis yang berupa kata-kata/kalimat dalam percakapan serta penggambaran tingkah laku para tokoh cerita Nagasasra dan Sabuk Inten.

Pengumpulan data dilakukan dengan membaca dan mengkaji secara cermat terhadap kalimat-kalimat yang berupa dialog dan penggambaran tingkah laku para tokoh dalam cerita Nagasasra dan Sabuk Inten. Dari hasil pembacaan dan pengkajian tersebut diperoleh data kasar yang berupa kalimat-kalimat yang mencerminkan nilai moral. Kalimat-kalimat tersebut kemudian dicatat dalam kartu data.

Data dalam penelitian ini reduksi data berupa kalimat dalam percakapan dan penggambaran tingkah laku para tokoh sangat banyak jumlahnya dan tidak semuanya mengandung nilai moral seperti dalam daftar cocok. Oleh karena itu, diperlukan langkah reduksi data (penguranan data) dengan cara mengabaikan data yang tidak relevan.

Inferensi merupakan kegiatan intelektual untuk memaknai data dalam kaitannya dengan konteks data dalam rangka menemukan fenomena yang menjadi sasaran penelitian. Atau dengan kata lain, inferensi dimaksudkan untuk menemukan ciri-ciri yang tersembunyi yang terdapat dalam konteks data serta merupakan isi atau makna dari fenomena yang diteliti. Ciri atau fenomena yang tersembunyi dalam konteks data penelitian ini adalah nilai moral yang terkandung di dalam kalimat-kalimat pada cerita Nagasasra dan Sabuk Inten.

Tujuan analisis data adalah meringkas dan menyajikan data sehingga mudah dipahami dan ditafsirkan. Kegiatan analisis data ini tidak dimaksudkan untuk menemukan hasil penelitian, karena hasil penelitian sudah ditemukan pada tahap inferensi. Namun, dalam teknis pelaksanaannya kegiatan analisis tidak dapat dipisahkan dari tahap inferensi. Kegiatan analisis dan inferensi merupakan kegiatan yang bersifat iteratif (proses bolakbalik/maju mundur).

Validitas yang digunakan dalam penelitian ini adalah validitas semantik, yaitu dengan cara melihat sejauh mana data yang berupa kalimat percakapan dan penggambaran tingkah laku para tokoh dalam cerita Nagasasra dan Sabuk Inten dapat dimaknai sesuai dengan konteksnya. Krippendorf menyatakan bahwa semantic validity is the degree to which the analytical categories of texts correspond to the meanings these texts have for particular readers or the roles they play within a choosen context (Shelley, 1984). Adapun reliabilitas yang digunakan dalam penelitian ini adalah reliabilitas intrarater. Reliabilitas intrarater dilakukan dengan membaca serta meneliti secara berulang-ulang nilai moral dalam sumber data.

\section{HASIL}

Pertanyaan penelitian yang ingin dijawab dalam penelitian ini adalah apa sajakah muatan moral yang terkandung di dalam cerita Nagasasra dan Sabuk Inten seri I sampai dengan III. Penelitian mengenai muatan moral dalam cerita Nagasasra dan Sabuk Inten seri I - III memperoleh hasil sebagai berikut. 
Tabel 1. Muatan Moral

\begin{tabular}{lccccc}
\hline \multicolumn{1}{c}{ Nilai Moral } & Seri I & Seri II & $\begin{array}{c}\text { Seri } \\
\text { III }\end{array}$ & Jumlah & Persentase \\
\hline Nilai Tolong-menolong & 5 & 12 & 2 & 19 & $31,15 \%$ \\
Nilai Sopan-santun & 6 & 4 & $\mathbf{6}$ & 16 & $26,23 \%$ \\
Nilai Ketuhanan & 5 & 4 & 1 & 10 & $16,39 \%$ \\
Nilai Kesetiaan & 3 & 0 & 3 & 6 & $9,84 \%$ \\
Nilai Tanggung Jawab & 3 & 1 & 0 & 4 & $6,56 \%$ \\
Nilai Rendah Hati & 2 & 0 & 1 & 3 & $4,92 \%$ \\
Nilai Cinta pada Alam Sekitar & 0 & 2 & 0 & 2 & $3,28 \%$ \\
Nilai dalam Bentuk Tembang & & 1 & & 1 & $1,64 \%$ \\
\hline \multicolumn{1}{c}{ Jumlah } & $\mathbf{2 4}$ & $\mathbf{2 4}$ & $\mathbf{1 3}$ & $\mathbf{6 1}$ & \\
\hline
\end{tabular}

Dari tabel 1 di atas telihat bahwa nilai tolong-menolong merupakan nilai yang paling banyak ditemukan $(31,15 \%)$, kemudian diikuti oleh nilai sopan santun $(26,23 \%)$, nilai ketuhanan (16,39\%), nilai kesetiaan $(9,84 \%)$, nilai tanggung jawab $(6,56 \%)$, nilai rendah hati $(4,92 \%)$, nilai cinta terhadap alam $(3,28 \%)$, dan pesan moral dalam bentuk tembang $(1,64 \%)$

Berikut ini disajikan beberapa penggalan cerita yang memuat nilai moral sebagaimana terdapat dalam hasil penelitian.

\section{Nilai tolong-menolong.}

Nilai tolong-menolong dalam cerita Nagasasra dan Sabuk Inten seri I - III berwujud perbuatan yang bertujuan meringankan beban/kesulitan sesama manusia secara ikhlas dan tanpa pamrih apapun. Hal tersebut antara lain terdapat dalam beberapa penggalan cerita berikut ini.

Maka dengan bekal kepercayaannya terhadap Tuhan Yang Maha Esa, serta kepercayaannya terhadap diri sendiri, Mahesa Jenar mulai dengan perjalanannya justru pada malam yang kelam, untuk mencari daerah baru yang lebih baik untuk lebih mendekatkan diri kepada satu pengabdian terhadap sesama (Seri I halaman 7-8).

Sementara itu, Mahesa Jenar meneruskan - Kakang Mantingan, meski aku bukan lagi seorang prajurit, namun aku masih tetap ingin mengabdikan diriku. Sebab pengabdian yang sebenarnya tidak harus melulu ditujukan kepada raja, tetapi sebenarnya bahwa pengabdian harus ditujukan kepada rakyat. Karena itu aku akan merasa berbahagia sekali kalai aku dapat berbuat sesuatu untuk ketentraman hati (seri I halaman 138).

Ia menjadi terharu sekali mendengar ucapan gadis yang menyediakan dirinya sebagai tumbal keselamatan sekian banyak orang. Dengan tenangnya pula ia menjawab kata-kata Jaka Soka. "Jaka Soka yang dikenal sebagai seorang Bajak Laut yang menakutkan. Buat apa aku mengharap kau membebaskan jiwaku. Kalau aku terpaksa berkubur di tengah-tengah hutan Tambak Baya ini. Karena aku membela kebenaran, aku sama sekali tidak akan menyesal. Karena itu, selagi aku masih bernafas, kau tak akan dapat menyentuh gadis yang belum aku kenal sebelumnya ini (Seri II halaman 11).

Keluarga Gajah Sora seluruhnya hanyalah terdiri dari tiga orang kecuali pembantu-pembantunya. Gajah Sora dan istrinya yang ramah selalu melakukan kewajibannya dengan baik selaku seorang istri kepala Daerah Perdikan. Ia mengerti apa yang harus dilakukan, tidak hanya terhadap suaminya, tetapi juga kepada rakyatnya. Ia selalu siap memberikan pertolongan-pertolongan yang diperlukan oleh penduduk wilayahnya. Kemudian seorang anak laki-laki, putra Gajah Sora (Seri III halaman 76).

\section{Nilai sopan santun}

Nilai sopan santun terwujud dalam perbuatan saling menghormati sesama manusia dan menghargai adat istiadat yang berlaku di suatu daerah. Dalam cerita ini digambarkan juga bahwa dalam situasi yang serba tidak menguntungkan, kita tetap dituntut untuk 
berperilaku sopan santun. Hal tersebut antara lain terdapat dalam beberapa penggalan cerita berikut ini.

“Bolehkah aku bertanya?" kata Demang tua itu dengan nada yang berat tetapi sopan dan rumah. "Siapakah nama Ki Sanak dan dari manakah asal Ki Sanak? Sebab menurut pengamatan kami, Ki Sanak bukanlah orang dari daerah kami."

Mahesa Jenar sebenarnya sama sekali tidak senang diperlakukan sedemikian, tetapi ia tidak ingin ribut-ribut. Maka dijawabnya pertanyaan itu dengan sopan pula,

"Bapak Demang, kalau Bapak Demang ingin mengetahui, aku berasal dari Pandanaran. Aku adalah pegawai istana Demak, yang karena sesuatu hal ingin menjelajahi daerahdaerah wilayah Kerajaan Demak.” (Seri I halaman 13)

Perlakuan orang itu sebenarnya sudah keterlaluan. Tetapi Mahesa Jenar masih berusaha untuk menahan diri, dan menjawab dengan baik. "Apa yang perlu kau ketahui telah aku katakan.” (Seri I halaman 15).

Setelah sampai di hadapan orang itu, segera Mahesa Jenar membungkuk hormat. Orang itu ternyata juga orang yang ramah dan sopan. Karena itu sambil tertawa ia pun membungkuk hormat. Malahan sebelum Mahesa Jenar bertanya, ia sudah mendahuluinya. "Selamat datang di daerah ini Anakmas, rupa-rupanya Anakmas memerlukan pertolonganku?" Mendapat sambutan yang demikian ramahnya serta tak diduga-duga, Mahesa Jenar terperanjat. Maka cepat-cepat dijawabnya. "Mudah-mudahan kedatanganku tidak mengganggu pekerjaan Bapak.” (Seri II halaman 136).

Di muka pendapa itu telah banyak orang berjajar-jajar menanti. Diantara mereka berdiri seorang perempuan. Ketika iring-iringan itu sampai di muka pendapa, segera Ki Ageng Gajah Sora dan Mahesa Jenar turun dari kuda, dan berjalan ke arah para penyambut. Sampai di muka tangga, perempuan itu segera mengambil siwur dan mencuci kaki Ki Ageng Gajah Sora. Orang itulah Nyi Ageng Gajah Sora. Setelah Nyi Ageng Gajah Sora mencuci kaki suaminya maka dipersilahkan Mahesa Jenar mencuci kakinya, dan seterusnya bergantiganti dengan mereka yang turut serta menjemput kedatangan Gajah Sora dan Mahesa Jenar. Setelah itu Gajah Sora suami-istri bersama-sama dengan Mahesa Jenar langsung menuju ke Pringgitan (Seri III halaman 73).

\section{Nilai Ketuhanan}

Nilai ketuhanan terwujud dalam perbuatan mendekatkan diri kepada Tuhan. Perbuatan tersebut tentu lebih dahulu didasari oleh rasa percaya terhadap eksistensi kekuasaan Tuhan serta keyakinan bahwa jika kita semakin dekat dengan Tuhan maka Tuhan akan semakin dekat pula dengan kita. Barangsiapa dekat dengan Tuhannya, maka dia akan mendapatkan ketenteraman hati, ketenangan jiwa, kejernihan berfikir, dan ketabahan dalam menghadapi berbagai tantangan kehidupan. Hal tersebut antara lain terdapat dalam beberapa penggalan cerita berikut ini.

- Aku (Mahesa Jenar) telah menanggalkan pakaian keprajuritanku dan telah menyisihkan segala macam senjata - katanya - dengan suatu keinginan untuk mendekatkan diri kepada Tuhan (Seri I halaman 35).

- Anakmas - katanya - sebenarnya bukanlah pertolongan yang aku berikan, tetapi sematamata hanyalah karena kebetulan saja dan terutama atas kehendak Tuhan. Aku bukanlah orang yang mempunyai kepandaian yang cukup untuk bertanding. Kalau pada masa mudaku sekali dua kali aku pernah terlibat dalam suatu pertarungan, itu sama sekali bukan karena aku mampu melakukannya, tetapi itu hanyalah karena kebodohanku dan kesombonganku yang kosong - (Seri I halaman 40).

Sudah tentu Mahesa Jenar tidak dapat berpangku tangan menyaksikan semua itu terjadi. Ia telah berjanji kepada dirinya sendiri, mengabdikan diri bagi kedamaian hati rakyat dan 
kemanusiaan. Sebab dengan demikian ia telah mengabdikan dirinya pula kepada tanah tumpah darah dan kepada Tuhan Yang Maha Esa (Seri II halaman 10).

Sepi malam yang mencengkam itu kemudian dipecahkan oleh suara Ki Lemah Telasih. "Ki Ageng, luka-luka Ananda Arya tidaklah begitu berat. Mudah-mudahan atas kemurahan Allah Yang Maha Kuasa, dalam waktu yang singkat luka itu akan segera sembuh kembali." (Seri III halaman 151).

\section{Nilai Kesetiaan}

Kesetiaan adalah sikap dan perbuatan yang tetap dan teguh hati dalam berbagai hal, seperti pendirian, prinsip hidup, ikatan persahabatan, ikatan keluarga (suami/istri/anak), tugas atau jabatan, terhadap bangsa dan negara, serta terhadap janji. Hal tersebut antara lain terdapat dalam beberapa penggalan cerita berikut ini.

Telah bertahun-tahun Mahesa Jenar mengabdikan dirinya kepada Negara sebagai seorang prajurit. Tetapi karena masalah perbedaan ajaran tentang kepercayaan, yang telah menimbulkan beberapa korban, ia terpaksa mengundurkan diri, meskipun kesetiannya kepada Demak tidak juga susut (Seri I halaman 7).

Tetapi hal yang membesarkan hatiku adalah, bahwa anakku tetap setia pada janjinya, meskipun laki-laki yang dikaguminya itu telah cacat. Sehingga perkawinan mereka pun dapat dilangsungkan," jelas Ki Asem Gede (Seri I halaman 117).

Di muka pendapa itu telah banyak orang berjajar-jajar menanti. Diantara mereka berdiri seorang perempuan. Ketika iring-iringan itu sampai di muka pendapa, segera Ki Ageng Gajah Sora dan Mahesa Jenar turun dari kuda, dan berjalan ke arah para penyambut. Sampai di muka tangga, perempuan itu segera mengambil siwur dan mencuci kaki Ki Ageng Gajah Sora. Orang itulah Nyi Ageng Gajah Sora. Setelah Nyi Ageng Gajah Sora mencuci kaki suaminya maka dipersilahkan Mahesa Jenar mencuci kakinya, dan seterusnya bergantiganti dengan mereka yang turut serta menjemput kedatangan Gajah Sora dan Mahesa Jenar. Setelah itu Gajah Sora suami-istri bersama-sama dengan Mahesa Jenar langsung menuju ke Pringgitan (Seri III halaman 73).

\section{Nilai Tanggung Jawab}

Tanggung jawab adalah sikap hati dan perilaku untuk sanggup menjalankan tugas/memikul beban yang diberikan disertai kerelaan untuk menanggung segala resiko yang diterima akibat tugas atau beban tersebut. Hal tersebut antara lain terdapat dalam beberapa penggalan cerita berikut ini.

Terbayang betapa demang tua itu telah berusaha mati-matian untuk melindungi rakyatnya sampai ia tidak memikirkan nasibnya sendiri (Seri I halaman 39).

- Rupa-rupanya pemimpin rombongan pedagang itu sudah amat berpengalaman menempuh perjalanan yang demikian. Karena itu tampaklah bijaksana ia membawa orang-orang yang berada di bawah tanggung jawabnya, Apabila jalan amat sulit, tidak segan-segan ia menolong, bahkan menggendong para wanita dalam rombongannya itu (Seri I halaman 145).

\section{Nilai Rendah Hati}

Rendah hati adalah sikap dan perbuatan yang tidak angkuh atau tidak sombong. Orang yang rendah hati adalah orang yang tidak suka menonjolkan kemampuan atau kelebihan yang ada pada dirinya. Hal tersebut antara lain terdapat dalam beberapa penggalan cerita berikut ini.

"Anakmas, sebenarnya bukanlah pertolongan yang aku berikan, tetapi semata-mata hanyalah karena kebetulan saja dan terutama atas kehendak Allah. Aku bukanlah orang yang mempunyai kepandaian yang cukup untuk bertanding. Kalau pada masa mudaku, sekali dua 
kali aku pernah terlibat dalam suatu pertarungan, itu sama sekali bukan karena aku mampu melakukannya, tetapi itu hanyalah karena kebodohan dan kesombonganku yang kosong saja (Seri I halaman 39).

Sebentar kemudian kembali orang itu berkata - Terima kasih atas pertolongan tuan Aku hanya membantu mempercepat penyelesaian saja. Ki Sanak pasti dapat menyelesaikan seorang diri - jawab Mahesa Jenar. Orang itu tertawa lirih, katanya melanjutkan - Tuan terlalu menyanjung aku. Tetapi, sebenarnya bahwa kedatangan Tuan menyelamatkan nyawaku (Seri III halaman 34-35).

\section{Nilai Cinta pada Alam Sekitar}

Di dalam cerita Nagasasra dan Sabuk Inten, selain terdapat moral terhadap sesama, juga terdapat moral terhadap alam sekitar. Moral terhadap alam sekitar berupa sikap dan perilaku sayang/cinta kasih terhadap hewan, tumbuh-tumbuhan, dan berbagai kekayaan alam yang ada di muka bumi. Hal tersebut antara lain terdapat dalam beberapa penggalan cerita berikut ini.

Tetapi di samping itu ia menjadi kagum pada Mahesa Jenar yang mempunyai sifat-sifat yang tak pernah dijumpai dalam tata pergaulan di sarangnya. Dan tiba-tiba saja ia merasa kengerian dan kejemuan untuk dapat bertemu dengan gerombolannya kembali, yang tak pernah meraskan betapa indahnya hidup manusia yang dapat menikmati terbitnya fajar dan serta bulatnya bulan. Serta betapa tentramnya hidup ini apabila ia berkesempatan mengagungkan alam. Lebih-lebih penciptanya. Tuhan yang Maha Agung. Hal yang demikian tidaklah pernah dialami selama ia hidup di dalam sarang gerombolannya. Di mana setiap saat hanyalah berlaku kekuasaan dan pembunuhan bagi mereka yang tidak mentaati peraturan (Seri I halaman 56).

\section{Nilai dalam Bentuk Tembang}

Dalam cerita Nagasasra dan Sabuk Inten, pengungkapan nilai moral tidak hanya dalam bentuk dialog atau penggambaran tingkah laku saja. Pada Seri II halaman 33 terdapat pengungkapan nilai moral dalam bentuk tembang (lagu Jawa), yang berupa tembang Dandanggula. Bunyi tembang selengkapnya adalah sebagai berikut.

Lir sarkara, wasitaning jalmi,

Ambudiya budining sasatya,

Memayu yu buwanane,

Ing reh hardening kawruh,

Wruhing karsa kang ambeg asih,

Sih pigunaning karya,

Mbrasta ambeg dudu,

Mengenep nenging cipta,

Wruh unggyaning tindak kang ala becik,

Memuji tyas raharja.

Beberapa hal penting yang dapat disarikan dari isi tembang Dandanggula di atas adalah sebagai berikut.

a. Manusia harus memiliki pengetahuan yang luas sebagai bekal untuk mengarungi kehidupan. Hal ini menyiratkan makna bahwa manusia harus selalu belajar untuk memperoleh dan menambah pengetahuan. Belajar di sini tidak terbatas oleh umur dan harus di bangku sekolah, namun belajar dalam arti yang luas sesuai dengan prinsip belajar sepanjang hayat (long life education).

b. Manusia harus memiliki sifat cinta kasih terhadap sesama dalam bentuk tindakan saling tolong-menolong, saling menghormati, dan sebagainya.

c. Kejahatan dan kesewenang-wenangan harus diperangi serta diberantas karena merugikan sesama manusia. 
d. Dengan hati, pikiran, dan perasaannya manusia harus mampu membedakan mana yang baik dan mana yang buruk.

e. Senantiasa berdoa dan beribadah kepadaTuhan agar selalu mendapat ketentraman serta kebahagiaan hidup.

\section{PEMBAHASAN}

Makna cerita Nagasasra dan Sabuk Inten sebenarnya adalah penggambaran tentang sosok pemimpin yang ideal. Pemimpin yang ideal yang dimaksud dalam cerita ini adalah pemimpin yang berjiwa dan berwatak seperti keris Nagasasra dan Sabuk Inten, serta keris Kyai Sengkelat. Dalam seri VII halaman 146 disebutkan bahwa keris Nagasasra berjiwa disuyuti kawula (disegani dan dicintai oleh rakyatnya), merupakan pancaran dari sinar kasih Tuhan, berjiwa perikemanusiaan, dan memberi perlindungan kepada siapa saja yang membutuhkan. Keris Sabuk Inten memiliki watak seperti lautan yang begitu luas seolah tak bertepi, yang mampu menampung arus sungai dan banjir dari manapun datangnya, namun pada suatu saat gelombangnya dapat menunjukkan kedahsyatannya. Sebagai pelengkap dari keris Nagasasra dan Sabuk Inten adalah keris Kyai Sengkelat. Keris Kyai Sengkelat mempunyai jiwa dan watak yang lengkap dari watak dan jiwa seorang prajurit, yang senantiasa setia dan patuh terhadap tanah air dan bangsanya.

Penggambaran watak keris-keris tersebut sebenarnya menggambarkan hubungan antara kepemimpinan dan kekuasaan. Kepemimpinan dan kekuasaan adalah dua konsep yang berhubungan sangat erat. Kepemimpinan terbentuk karena ada relasi atau hubungan dengan orang lain yang disebut pengikut (Locke, E. A., \& Latham, 2002). Relasi yang terbangun antara pemimpin dan pengikutya adalah pemimpin mempengaruhi perilaku para pengikutnya dan proses pemimpin mempengaruhi pengikutnya untuk melakukan tindakan-tindakan dalam rangka mewujudkan tujuan yang telah disepakati bersama. Kepemimpinan yang efektif akan terwujud pada saat seorang pemimpin mampu menggugah pengikutnya sesuai dengan tujuan yang diinginkan (Rosenbusch, 2013). Pemimpin yang efektif adalah pemimpin yang disuyuti kawula (disegani dan dicintai oleh rakyatnya), sebagaimana sifat dari keris Nagasasra. Sifat lain dari keris Nagasasra adalah berjiwa perikemanusiaan dan memberi perlindungan kepada siapa saja yang membutuhkan. Hal ini sesuai dengan konsep kepemimpinan Hasta Brata. Hasta berarti delapan, adapun Brata mempunyai arti perbuatan atau laku (Hudaya \& Nugroho, 2013). Dengan demikian, Hasta Brata berarti delapan perbuatan atau laku utama yang harus dimiliki dan dilakukan oleh seorang pemimpin. Salah satu sifat pemimpin berdasarkan Hasta Brata yang relevan dengan sifat keris Nagasasra adalah bahwa seorang pemimpin harus bisa seperti sifat bumi. Bumi adalah tempat berbagai mahluk hidup dan mahluk tak hidup. Bumi merupakan tempat yang kokoh di mana semua kebutuhan dasar mahluk hidup tersedia. Bumi juga adalah tempat perlindungan bagi semua mahluk hidup tanpa memandang perbedaan yang ada. Seperti halnya bumi, pemimpin harus mampu untuk memberi tanpa pamrih kepada semua masyarakat yang ia pimpin dan kokoh dan menjadi tempat pertama yang bisa diandalkan (Yasasusastra, 2011).

Keris Sabuk Inten memiliki watak seperti lautan yang begitu luas seolah tak bertepi, yang mampu menampung arus sungai dan banjir dari manapun datangnya, namun pada suatu saat gelombangnya dapat menunjukkan kedahsyatannya. Sesuai dengan watak dan jiwa keris Sabuk Inten, seorang pemimpin harus mau dan mampu menampung setiap masukan, baik berupa dukungan maupun kritikan. Berbagai masukan dan kritikan tersebut kemudian diolah dan digunakan untuk kesejahteraan rakyatnya. Di sisi lain, seorang pemimpin harus bisa menunjukkan ketegasan dalam memikul tanggung jawab yang dibebankan kepadanya. Dalam konteks kepemimpinan Hasta Brata, sifat pemimpin yang melekat pada keris Sabuk Inten adalah samudera atau lautan yang sangat luas. Samudera adalah muara dari semua sungai. Tidak semua sungai membawa air yang bersih. Samudera, dengan keluasannya menerima air dari sungai manapun, baik kotor kotor atau bersih. Seperti halnya samudera, pemimpin adalah sosok yang terbuka dan memiliki 
pemikiran luas. Pemimpin harus mampu menerima pendapat atau kritik dari orang lain. Samudera, selain juga menampung berbagai air sungai, juga mengolah semua air sungai tersebut di kedalaman airnya dan di keluasannya. Hal ini juga harus dimiliki oleh seorang pemimpin. Seorang pemimpin tidak boleh menelan mentah-mentah masukan atau informasi yang datang. Ia memikirkan baik-baik semua pendapat yang ada dan menglahnya demi tujuan kesejahteraan rakyatnya. Dengan berbagai informasi, masukan, dan kritik yang diolah dengan baik, maka si pemimpin akan mendapatkan pengetahuan baru dari sekitarnya (Yasasusastra, 2011).

Keris Kyai Sengkelat adalah keris pelengkap dari keris Nagasasra dan Sabuk Inten. Seperti halnya keris Nagasasra dan Sabuk Inten, keris Kyai Sengkelat juga memiliki watak seorang pemimpin. Keris Kyai Sengkelat mempunyai jiwa dan watak yang lengkap dari watak dan jiwa seorang prajurit, yang senantiasa setia dan patuh terhadap tanah air dan bangsanya. Cinta tanah air adalah perilaku yang menunjukan kepedulian, penghargaan, yang dilandasi semangat kebangsaan dan rela berkorban demi nusa dan bangsa (Atika, Wakhuyudin, \& Fajriyah, 2019). Dalam cerita Nagasasra dan Sabuk Inten, tokoh Mahesa Jenar, Gajah Sora, dan tokoh-tokoh protagonis lainnya mencerminkan sosok nasionalis (cinta tanah air dan bangsa). Mereka sanggup berjuang dan mengorbankan apa saja demi kejayaan negara Demak.

Ada satu hal yang cukup menarik yang diungkap oleh S.H. Mintardja mengenai hubungan dengan sifat keris dan seorang pemimpin. Dalam cerita ini S.H Mintardja mengungkapkan dengan bahasa yang simbolis namun begitu lugas bahwa walaupun seseorang telah menguasai keris Nagasasra dan Sabuk Inten, namun itu saja tidak cukup sebagai bekal untuk menjadi pemimpin yang diidamkan oleh rakyat. Selama jiwa kedua keris itu belum menyatu dengan jiwa pemegangnya, maka cita-cita menjadi raja tidak akan tercapai. Selama masih ada jarak antara jiwa kedua keris itu dengan jiwa pemegangnya, maka selama itu pula keris yang dikatakan keramat itu tidak akan berguna. Kedua keris itu akan berguna manakala jiwa keris itu telah menyatu dengan jiwa pemegangnya. Pertanda bahwa keris itu telah menyatu adalah kedua keris itu kehilangan pamor/kecemerlangannya. Kedua keris itu tidak lagi berwarna kebiru-biruan dan kekuning-kuningan, tapi tak ubahnya seperti besi biasa saja.

Pemaknaan tentang jiwa keris Nagasasra dan Sabuk Inten tersebut mengandung maksud bahwa harus ada kesesuaian antara jiwa keris Nagasasra dan Sabuk Inten dengan jiwa pemegangnya. Keris-keris tersebut hanyalah alat belaka, bukan faktor penentu dari sifat kepemimpinan. Artinya, untuk menjadi pemimpin yang ideal dibutuhkan keteladanan yang sesuai dengan jiwa keris-keris tersebut. Keteladanan menjadi kunci bagi seorang pemimpin untuk menghadapi berbagai masalah di lapangan (Schaver, 2010). Pemimpin dengan penuh keteladanan akan berakibat pada semakin kuatnya tampuk pemerintahannya. Dengan demikian, antara keteladanan dengan kepemimpinan memiliki hubungan timbal balik yang bersifat positif atau saling memiliki kontribusi (Runtu, 2003).

\section{SIMPULAN}

Simpulan yang diperoleh dari hasil pembahasan mengenai muatan moral dalam cerita Nagasasra dan Sabuk Inten seri I sampai dengan III adalah sebagai berikut.

1. Cerita Nagasasra dan Sabuk Inten merupakan pertarungan antara kejahatan/kemunkaran melawan kebajikan/nilai ketuhanan dan kemanusiaan. Yang menjadi pemenang dalam pertarungan tersebut adalah nilai-nilai kebajikan karena setiap kejahatan/kemunkaran/pengingkaran terhadap hukum-hukum-Nya pasti akan hancur. Pertarungan antara kejahatan dengan kebajikan dalam cerita ini diwujudkan dalam berbagai penggambaran tingkah laku.

2. Selain mengunakan media dialog antartokoh dan penggambaran tingkah laku para tokoh, pesan moral dalam cerita Nagasasra dan Sabuk Inten juga menggunakan media lain. Media lain yang digunakan adalah dalam bentuk tembang (lagu), yang berupa tembang Dandanggula, yang terdapat dalam seri II. Dalam tembang tersebut 
tersirat berbagai tuntunan tentang bagaimana hidup dalam suatu tatanan masyarakat.

3. Cerita Nagasasra dan Sabuk Inten seri I - III menempatkan nilai tolong-menolong sebagi nilai yang dominan, selain nilai ketuhanan dan sopan santun. Ketiga nilai tersebut ditemukan di seri I, II, dan III.

4. Cerita Nagasasra dan Sabuk Inten menekankan arti pentingg berdoa, bersyukur, pasrah terhadap Tuhan YME, dan bekerja keras. Mahesa Jenar dan tokoh-tokoh golongan putih lainnya merupakan lambang dari sosok yang religius, yan selalu berdoa dan pasrah diri kepada Tuhan YME dalam setiap usahanya. Adapun tokoh golongan hitam, seperti Jaka Soka, Lawa Ijo, Sima Rodra, dan sebagainya, merupakan pencerminan sosok yang tidak percaya terhadap eksistensi Tuhan YME. Mereka terlalu percaya kepada kemampuan diri sendiri dan menafikan eksistensi Tuhan dalam setiap usahanya.

5. Cerita Nagasasra dan Sabuk Inten menggambarkan bahwa ketamakan atau sifat rakus dapat menjadi penyebab perbuatan jahat lainnya. Semua kekacauan yang terjadi di Banyubiru dan Kerajaan Demak berpangkal dari sifat tamak/rakus akan kamukten (kekuasaan).

6. Secara tersirat cerita Nagasasra dan Sabuk Inten menyinggung tentang arti penting keutuhan dan keharmonisan sebuah rumah tangga. Perilaku jahat Lawa Ijo dan Umbaran merupakan akibat dari keadaan keluarga yang tidak harmonis. Lawa Ijo berasal dari keluarga yang tidak harmonis. Ia tega membunuh istrinya karena disangka berbuat serong dengan lelaki lain. Umbaran juga berasal dari keluarga yang tidak harmonis. Ayahnya seorang pemabuk dan penjudi yang hampir tidak pernah pulang ke rumah, sedangkan ibunya adalah wanita yang tidak setia, yang mudah tergoda oleh laki-laki lain karena iming-iming uang dan perhiasan. berikut.

Beberapa saran yang disampaikan sehubungan dengan penelitian ini adalah sebagai

Dalam cerita Nagasasra dan Sabuk Inten terdapat banyak penulisan yang tidak sesuai dengan kaidah ejaan Bahasa Indonesia. Sebagai contoh, awalan di - yang diikuti kata keterangan tempat tertulis disambung. Hal tersebut terdapat pada kata di sana ditulis disana, di pendapa ditulis dipendapa, dan sebagainya. Oleh karena itu, kepada Badan Penerbit Kedaulatan Rakyat apabila menerbitkan edisi revisi hendaknya merevisi pula ejaan di dalamnya, tentunya dengan tanpa merubah isi dan alur cerita.

Masyarakat umum perlu mengetahui isi cerita Nagasasra dan Sabuk Inten secara utuh, mengingat terdapat banyak muatan moral yang dapat dijadikan teladan.

Cerita Nagasasra dan Sabuk Inten akan semakin dikenal luas, tidak hanya pada masyarakat Jawa Tengah dan DIY, apabila disebarluaskan dalam bentuk cerita bergambar (cergam), dalam bentuk sinetron di televisi, atau bahkan film.

Para pendidik di bidang moral bisa menggunakan muatan moral dalam cerita Nagasasra dan Sabuk Inten sebagai bahan diskusi bagi para peserta didiknya.

\section{DAFTAR PUSTAKA}

Abdulrani, S. (1996). Ikhtisar Sastra Indonesia. Bandung: Pustaka Setia.

Arikunto, S. (2013). Prosedur Penelitian Suatu Pendekatan Praktik. Jakarta: PT Rineka Cipta.

Atika, N. T., Wakhuyudin, H., \& Fajriyah, K. (2019). Pelaksanaan penguatan pendidikan karakter membentuk karakter cinta tanah air. Mimbar Ilmu, 24(1), 105-113. https://doi.org/10.23887/mi.v24i1.17467

Hudaya, Z. A., \& Nugroho, S. W. D. (2013). Kearifan lokal budaya Jawa sebagai basis model kepemimpinan yang efektif. Sustainable Competitive Advantage (SCA), 3(1). Retrieved from http://jp.feb.unsoed.ac.id/index.php/sca-1/article/view/222 
Locke, E. A., \& Latham, G. P. (2002). Building a practically useful theory of goal setting and task motivation. American Psychologist, A 35. https://doi.org/doi.org/10.1037/0003-066X.57.9.705

Mintardja, S. (1983). Nagasasra dan Sabuk Inten. Yoyakarta: Badan Penerbit Kedaulatan rakyat.

Moleong, L. J. (2014). Metodologi Penelitian Kualitatif Edisi Revisi. Bandung: PT Remaja Rosdakarya.

Prijanto, S. (2014). Makna Kejantanan dan Kesetiaan dalam Nagasasra dan Sabuk Inten Karya S. H. Mintardja. Jurnal Aksara, 26(2), 169-187.

Nurgiyantoro, B. (2000). Teori Pengkajian Fiksi. Yogyakarta: Gadjah Mada University Press.

Rengganis, R. (2017). Sastra Idealis Versus Industri Kreatif: Studi Kasus Film Nay sebagai Bentuk Filmisasi Novel Nayla Karya Djenar Mahesa Ayu. Jurnal Bahasa dan Sastra Indonesia Serta Pengajarannya, 3(1), 42-58. DOI?

Rosenbusch, K. (2013). Effective Leadership. European Journal of Training and Development, 37 No. 8. https://doi.org/doi.org/10.1108/EJTD-05-2013-0065

Runtu, B. W. (2003). Determinan kepemimpinan. Makara Human Behavior Studies in Asia, 7(2), 71. https://doi.org/10.7454/mssh.v7i2.57

Sayuti, S. A. (2000). Berkenalan dengan Prosa Fiksi. Yogyakarta: Gama Media.

Schaver, A. J. (2010). Effective leaders and leadership in policing: traits, assessment, development and expansion. Policing: An International Journal, 33( 4), 644-663. https://doi.org/doi.org/10.1108/13639511011085060

Shelley, M. (1984). Content-Analysis - An Introduction to Its Methodology - Krippendorff,K. Journal of the American Statistical Association, 79(385), 240. Retrieved from isi:A1984SJ28000060

Sigit, S. (1999). Pengantar Metodologi Penelitian Sosial, Bisnis, dan Manajemen. Yogyakarta: Lukman Offset.

Soenarjati dan Cholisin. (1989). Dasar dan Konsep Pendidikan Moral. Yogyakarta: Laboratorium Jurusan PMP\&KN FPIPS IKIP Yogyakarta.

Widodo, J. (2016). Konstruksi Pengetahuan Jawa dalam Novel Nagasasra dan Sabuk Inten Karya SH Mintardja. Universitas Negeri Malang.

Yasasusastra, J. S. (2011). Hasta Brata 8 Unsur Alam Simbol Kepemimpinan. Yogyakarta: Pustaka Mahardika. 